\title{
Effect of $P$ depletion on the functional pools of diatom carbohydrates, and their utilization by bacterial communities
}

\author{
Labry Claire 1, ", Delmas Daniel ${ }^{1}$, Moriceau Brivaela ${ }^{2}$, Gallinari Morgane ${ }^{3}$, Quere Julien ${ }^{1}$, \\ Youenou Agnes ${ }^{1}$
}

1 Ifremer, DYNECO, F-29280 Plouzané, France

2 Univ Brest, CNRS, IRD, Ifremer, LEMAR, F-29280 Plouzané, France

3 Univ Brest, CNRS, IRD, Ifremer, LEMAR, F-29280 Plouzané, France

*Corresponding author : Claire Labry, email address : clabry@ifremer.fr

\begin{abstract}
:
Phosphorus $(\mathrm{P})$ limitation of phytoplankton growth is known to affect the accumulation and release of carbohydrates $(\mathrm{CHO})$ by micro-algae. However, relatively little is known about the fate of algal exudates, notably their bacterial degradation. The $\mathrm{CHO}$ chemical characterization is also not exhaustive, especially in 'functional' pools relevant for phytoplankton physiology (particulate reserve $[R]$ or structural $[\mathrm{S}] \mathrm{CHO}$ ) and for bacterial degradation (dissolved mono- [MDCHO] and polysaccharides [P-DCHO]). In this study, we investigated how $\mathrm{P}$ depletion and repletion affect the $\mathrm{CHO}$ composition in diatom Thalassiosira weissflogii cultures, and the shortterm response of free and diatom-attached bacteria in terms of abundance and potential Bglucosidase activity $(\beta G \mathrm{lc})$. The bacterial inoculum was composed of the bacterial consortiums of diatom precultures and a natural bacterial community from the Bay of Brest. $\mathrm{P}$ depletion favored $\mathrm{CHO}$ accumulation in diatom cells, mainly as $\mathrm{R}$ i.e. soluble $\mathrm{CHO}$ accumulated in cytoplasm, but also as S, polysaccharides linked to the cell wall. The R:S ratio was high in the present diatom cultures. The high M-DCHO observed in P-deplete cultures (twice that of P-replete cultures) when $\mathrm{P}-\mathrm{DCHO}$ remained quite similar is explained both by active polysaccharide hydrolysis (very high potential $\beta \mathrm{Glc}$ of attached bacteria) and reduced uptake of $\mathrm{M}-\mathrm{DCHO}$ by Pdepleted bacteria. $\mathrm{P}$ depletion of heterotrophic bacteria favors labile $\mathrm{CHO}$ accumulation, which may affect particle potential aggregation. However, the remarkably constant $\mathrm{M}-\mathrm{DCHO}$ concentration over time for both conditions suggests tight coupling between phytoplankton accumulation, release, polymer hydrolysis and monomer uptake by bacteria.
\end{abstract}

Keywords : P limitation, Phytoplankton, Diatom, Bacteria, Mineralization, Carbohydrate, Glucosidase 


\section{Introduction}

Carbohydrates $(\mathrm{CHO})$ are important constituents of living matter, especially in phytoplankton where cellular carbohydrates can account for up to $90 \%$ of organic dry matter (Myklestad 1974). The production and excretion of CHO by phytoplankton have received significant attention in the past two decades as excreted $\mathrm{CHO}$ strongly influence particle aggregation and ultimately the export of organic material towards the deep sea (Mari et al. 2017). The nutritional condition for micro-algal growth is a key factor in the cell $\mathrm{CHO}$ accumulation. Nitrogen $(\mathrm{N})$ and Phosphorus $(\mathrm{P})$ limitations are known to favor the production and excretion of CHO by diatoms (Myklestad 1995, Urbani et al. 2005, Suroy et al. 2015). However, the effect of $\mathrm{P}$ limitation seems to be higher than that of $\mathrm{N}$ limitation and this effect could increase with the degree of P depletion (Guerrini et al. 1998). The increasing N:P stoichiometry in aquatic ecosystems, in coastal ecosystem due to agricultural practices (Grizzetti et al. 2012, Penuelas et al. 2013) but also in oligotrophic ecosystems (Karl et al. 2001, Lomas et al. 2010), stresses the need for a better understanding of the effect of P limitation on phytoplankton dynamics.

While the physiological responses of phytoplankton species to nutritional condition has been largely studied, little is known about the fate of excreted phytoplankton $\mathrm{CHO}$. The fate of algal $\mathrm{CHO}$ is linked to the bacterial degradation of $\mathrm{CHO}$ polymers into monomers. The polysaccharides excreted by algae might actually stimulate the bacterial hydrolysis into monosaccharides, the subsequent uptake of monosaccharides by bacteria and, consequently, bacterial growth (Middleboe et al. 1995). Bacteria can also act as competitors at low phosphate $\left(\mathrm{PO}_{4}\right)$ concentrations, which can increase algal $\mathrm{P}$ depletion 
and their subsequent polysaccharide accumulation (Guerrini et al. 1998). Bacteria may themselves be P limited (Cotner et al. 1997, Thingstad et al. 1998), which slows their growth and, consequently, the hydrolysis of organic matter.

These bacterial responses depend on the bacterial physiological state and on the chemical composition of carbohydrates, which has been relatively unexplored (Le Costaouëc et al. 2017). Carbohydrates have usually been measured as total dissolved $\mathrm{CHO}$ and/or total particulate $\mathrm{CHO}$, without further fractionating between functionally different $\mathrm{CHO}$ pools. However, particulate $\mathrm{CHO}$ include structural (associated with cell wall) and reserve (intracellular) polysaccharides (Penna et al. 1999, Staats et al. 2000). Structural carbohydrates in diatoms are composed of acidic polysaccharides, often in the form of sulphated glucuronomannans (Ford \& Percival, 1965), and of heteropolysaccharides (Handa 1969, Hecky et al. 1973). Reserve polysaccharides are mainly glucose polymers (Biersmith \& Benner 1998). The most common is chrysolaminarin, a soluble $\beta$-1,3-glucan with $\beta$-1,6-linked glucose branches (Myklestad \& Haug 1972, Obata et al. 2013). $\beta$-1,3glucan can account for up to $80 \%$ of cellular organic carbon in diatoms (Granum et al. 2002). When the monosaccharide composition of dissolved $\mathrm{CHO}$ in $\mathrm{P}$ replete and $\mathrm{P}$ deplete diatom cultures was detailed, glucose was found to be the dominant monomer (Urbani et al. 2005). Galactose, mannose, xylose and rhamnose are lower contributors (Aluwihare \& Repeta 1999). According to species, their contribution could increase in limiting P conditions (Magaletti et al. 2004, Urbani et al. 2005). High turnover rates of dissolved aldoses, notably glucose, found in natural diatom populations (Hama \& Yanagi 2001) and in Thalassiosira weissflogii cultures (Suroy et al. 2015) and the decreasing contribution of glucose in particulate matter polysaccharides during sinking (Handa \& 
Tominaga 1969), suggest that glucose and its polymers are bioreactive compounds. Heteropolysaccharides are more resistant to biological degradation than glucan.

Thus, reserve polysaccharides and dissolved glucans constitute bioavailable $\mathrm{CHO}$ pools. They are degraded by glycoside hydrolases (EC 3.2.1.-), which are endo- and exoenzymes capable of hydrolyzing the glycosidic bond between two carbohydrate moieties. $\beta$-glucosidases (EC 3.2.1.21) are broad-specificity enzymes catalyzing the hydrolysis of terminal $\beta$-linked $(\beta-1-2 ; \beta-1-3 ; \beta-1-4 ; \beta-1-6)$ disaccharides of glucose (Chrost 1989). Since glucans are essentially composed of $\beta$-1,3- and $\beta$-1,6-linked glucoses, $\beta$ glucosidases must be largely used in their bacterial degradation.

The present work investigates how $\mathrm{P}$ limitation affects the physiological responses of phytoplankton cells, i.e. Thalassiosira weissflogii, a model diatom, with a particular attention to $\mathrm{CHO}$ composition and their utilization by bacteria. Particulate $\mathrm{CHO}$ were separated into structural (S) and reserve (R) carbohydrates, and dissolved CHO into mono- (M-DCHO) and polysaccharides (P-DCHO). This fractioning enables to discriminate between constitutive (S) and reactive pools (R), and between $\beta$-glucosidase substrates (P-DCHO) and hydrolysis products (M-DCHO). Since transparent exopolymer particles (TEP) are usually involved in the issue of particle aggregation, the TEP concentration was also evaluated. In parallel, the short-term response of free $(0.2-3 \mu \mathrm{m})$ and particle-attached (> $3 \mu \mathrm{m})$ bacteria was evaluated, in terms of biomass and potential $\beta$ Glc. In the case of $T$. weissflogii, its chrysolaminarin was isolated, characterized and found to have a low degree of polymerization and no $\beta-1,6$ branches, which makes it an easily accessible substrate for $\beta$-glucosidases (Storseth et al. 2005). 


\section{Materials and methods}

\subsection{Culture conditions}

\section{Precultures}

Non-axenic batch cultures of the diatom Thalassiosira weissflogii (AC813, Bay of Veys, France) were grown in f/2 medium (Guillard \& Ryther 1962) in filtered $(<0.2 \mu \mathrm{m})$ seawater from the Bay of Brest (salinity of 34). Prior to the experiment, cultures were preconditioned in media differing only in the initial $\mathrm{PO}_{4}$ concentration. The $\mathrm{P}$ replete condition contained $18 \mu \mathrm{M} \mathrm{PO}_{4}$ with a $\mathrm{N}: \mathrm{P}$ molar ratio of 18 , and the $\mathrm{P}$ limiting condition contained $4 \mu \mathrm{M} \mathrm{PO}_{4}$ and a N:P molar ratio of 80 (Fig. 1). For both media, nitrate + nitrite and silicate final concentrations were $320 \mu \mathrm{M}$ and $250 \mu \mathrm{M}$, respectively (a N:Si molar ratio of 1.3), and micronutrient concentrations reached $\mathrm{f} / 2$ conditions. Cells were grown for 4 days before being harvested, which corresponded to the mid- and end of exponential growth phase for P replete and P limiting precultures, respectively.

\section{Cultures}

Seawater was collected in the Bay of Brest (salinity : 34). Initial phosphate, nitrate + nitrite and silicate concentrations in the collected seawater were $0.5,13.1$ and $8.7 \mu \mathrm{M}$, respectively. Within a few hours after collection, seawater was gently prefiltered through $0.8 \mu \mathrm{m}$ in order to preserve the natural bacterial community whilst removing predators and phytoplankton competitors. After filtration, seawater was distributed among six flasks (10 l) and enriched with two media (triplicates for each media) in order to have two different $\mathrm{P}$ treatments (Fig. 1): the same $\mathrm{P}$ replete condition as in preconditioning $(18 \mu \mathrm{M}$ $\mathrm{PO}_{4}$ ) and a $\mathrm{P}$ deplete condition (no $\mathrm{PO}_{4}$ addition). The latter condition creates a gradient of $\mathrm{P}$ depletion in time. The two media contained the same concentrations of nitrate + 
nitrite $(320 \mu \mathrm{M})$ and silicate $(245 \mu \mathrm{M})$. For each $\mathrm{P}$ treatment, batches were inoculated with the respective precultures of $T$. weissflogii with an initial concentration of 11700 cells $\mathrm{ml}^{-1}$ for both conditions (9-11\% of inoculum volume). The bacterial inoculum was 2.5-2.8 $10^{6}$ cells $\mathrm{ml}^{-1}$, which is realistic for experiments free of bacterial predators. The bacterial consortium of the experiment was composed both of the natural bacterial community of the Bay of Brest and the bacterial community associated with the diatom precultures. By comparing $\mathrm{P}$ deplete to $\mathrm{P}$ replete conditions, this experimental set up allows to study the effect of $\mathrm{P}$ depletion on the carbohydrate dynamics (micro-algal CHO production, excretion and bacterial degradation). Batches were inoculated in the evening (at $6 \mathrm{pm}$ ), preceding the first subsampling (at 10 am the next day, $16 \mathrm{~h}$ after). Cultures were grown at $18^{\circ} \mathrm{C}$, with a photon irradiance of $150 \mu \mathrm{mol} \mathrm{m} \mathrm{m}^{-2} \mathrm{~s}^{-1}$ in a $12: 12$ light/dark (L:D) cycle and a constant bubble flow of $0.2 \mu \mathrm{m}$ filtered air. Incident light was measured with a scalar photosynthetically active radiation (PAR) irradiance sensor (QSL-100, Biospherical Instruments).

To consider diurnal variation in CHO metabolism (Varum et al. 1986), each sampling was carried out exactly 4 hours after the beginning of the light phase, every $24 \mathrm{~h}$. The composition of the dissolved phase in terms of inorganic nutrients and $\mathrm{CHO}$, was determined as well as the composition of the particulate phase i.e. diatom, free and attached bacteria cell number, the elemental composition of particles $(\mathrm{C}, \mathrm{N}, \mathrm{P}, \mathrm{Si})$, the speciation of total particulate phosphorus (TPP) into particulate organic (POP) and inorganic phosphorus (PIP), particulate $\mathrm{CHO}$ and hydrolytic enzymatic activities (potential $\beta$-glucosidases, alkaline phosphatases). 


\subsection{Microalgae and bacteria cell count}

For T. weissflogii enumerations, samples were fixed with a few drops of Lugol's iodine and cells were counted with an inverse optical microscope (Utermöhl method). Samples for total and free $(<3 \mu \mathrm{m})$ bacterial abundance were preserved with borate buffered formaldehyde (2\% final concentration). Samples for free bacteria determination were prepared by prefiltration $(3 \mu \mathrm{m})$ of culture samples. Total bacteria were determined after pyrophosphate treatment (Velji \& Albright 1986), then free and total bacteria were enumerated by epifluorescence microscopy after staining with 4',6-diamidino-2phenylindole (DAPI; Porter \& Feig 1980). The number of particle-attached (> $3 \mu \mathrm{m}$ ) bacteria was calculated by subtracting $<3 \mu \mathrm{m}$ cell number from the total bacteria. The cell division rate of phytoplankton and bacteria was used as the reference for the specific growth rate $(\mu)$ in the rest of the manuscript i.e. measured as increase in cell densities. It was calculated by plotting the logarithm of cells against time and determining the slope according to the least square's criterion. A minimum of three sampling points was included in the calculation.

\subsection{Inorganic nutrients and particulate matter analysis}

Samples for the determination of dissolved $\left(\mathrm{PO}_{4}\right.$, nitrate + nitrite and $\left.\mathrm{CHO}\right)$ and particulate (POC, PON, TPP, POP, PIP, CHO) compounds were very carefully filtered (20 $\mathrm{ml}$ for each particulate analysis) on precombusted $\left(12 \mathrm{~h}\right.$ at $\left.400^{\circ} \mathrm{C}\right) 25 \mathrm{~mm}$ Whatman ${ }^{\circledR}$ GF/F. Filtrates and filters were deep frozen $\left(-20^{\circ} \mathrm{C}\right)$. Samples for the determination of silicate were filtered on $0.45 \mu \mathrm{m}$ cellulose acetate filters with a syringe filtration system. 
Filtrates were stored at $4^{\circ} \mathrm{C}$. For TEP analysis, samples $(10 \mathrm{ml})$ were gently filtered onto $0.4 \mu \mathrm{m}$ polycarbonate membranes and stained with $0.5 \mathrm{ml}$ of a $0.02 \%$ aqueous solution of Alcian blue in $0.06 \%$ acetic acid $(\mathrm{pH} 2.5)$ according to the method of Passow \& Alldredge (1995). Filters were kept frozen at $-20^{\circ} \mathrm{C}$. Samples for biogenic silica $\left(\mathrm{bSiO}_{2}\right)$ determination were filtered on $0.6 \mu \mathrm{m}$ polycarbonate membranes, rinsed with artificial seawater, then dried at $60^{\circ} \mathrm{C}$ for $24 \mathrm{~h}$ and stored at room temperature until digestion and analysis.

Nitrate plus nitrite, $\mathrm{PO}_{4}$ and silicate were determined according to classic methods using segmented flow analysis (Aminot et al. 2009). Particulate organic C and N (POC, PON) were analysed on a $\mathrm{CHN}$ analyser. For biogenic silica $\left(\mathrm{bSiO}_{2}\right)$ determination, after $0.2 \mathrm{M}$ sodium hydroxide digestion carried out as in Ragueneau et al. (2005), the supernatant was analyzed for silicic acid (Aminot et al. 2009). Total particulate phosphorus (TPP) and PIP were determined as precisely described in Labry et al. (2013), the original methods being that of Solorzano and Sharp (1980) for TPP and Aspila et al. (1976) for PIP. POP was calculated as the difference between TPP and PIP. The PIP comprises intracellular storage P forms (i.e. phosphate, pyro- and polyphosphate), a substantial part of di and triphosphate nucleotides and P adsorbed on cell wall (Labry et al. 2013).

The cellular C, N, P, Si content of T. weissflogii ( $\left.\mathrm{Q}_{\mathrm{C}}, \mathrm{Q}_{\mathrm{N}}, \mathrm{Q}_{\mathrm{P}}, \mathrm{Q}_{\mathrm{Si}}\right)$ were obtained by dividing POC, PON, TPP and $\mathrm{bSiO}_{2}$, respectively, by the corresponding cell number considering filtered volumes. The total bacterial $\mathrm{C}, \mathrm{N}$ and $\mathrm{P}$ were minor contributors to POC, PON and TPP, respectively. They could be estimated assuming a cell content of 20 and $50 \mathrm{fg} \mathrm{C}$ for free and fixed bacteria, respectively (Lee \& Fuhrman 1987, Simon et al. 1990), and a C:N and C:P atomic ratios equal to 4 and 50, respectively. Total bacterial C, 
N, P contributed to a maximum of $4 \pm 1 \%(n=9), 10 \pm 2 \%(n=12)$ and $19 \pm 4 \%(n=12)$ of POC, PON and TPP, respectively, in P deplete conditions. In replete conditions, their contributions were $3 \pm 0 \%, 5 \pm 1 \%$, and $3 \pm 0 \%(\mathrm{n}=12)$ of POC, PON and TPP, respectively.

\subsection{Dissolved, particulate carbohydrates and TEP analysis}

Dissolved carbohydrates were analyzed using the 2,4,6-tri-pyridyl-s-triazine (TPTZ) method of Myklestad et al. (1997). Briefly, monosaccharides (M-DCHO) were determined by direct reaction without hydrolysis, while total dissolved carbohydrates (TDCHO) were analyzed by TPTZ after $20 \mathrm{~h}$ hydrolysis by $0.1 \mathrm{M} \mathrm{HCl}$ at $100^{\circ} \mathrm{C}$ and neutralization (Burney \& Sieburth 1977). All measurements were conducted in triplicates, the relative mean standard deviation for all the analyzed samples were $1.2 \%$ for M-DCHO (range $0.16-3.4 \%$ ) and $2.7 \%$ (range $0.6-7.5 \%$ ) for T-DCHO. The polymeric dissolved carbohydrates (P-DCHO) were calculated as the difference between T-DCHO and MDCHO.

Particulate $\mathrm{CHO}$ were analyzed from the particulate matter collected on filters. Reserve carbohydrates $(\mathrm{R})$ were first extracted with milliQ water for $30 \mathrm{~min}$ at $100^{\circ} \mathrm{C}$ (Handa 1969). After centrifugation, the supernatant was kept for $\mathrm{CHO}$ analysis. The filter and the residual pellets were then hydrolyzed $\left(2 \mathrm{~N} \mathrm{H}_{2} \mathrm{SO}_{4}, 4 \mathrm{~h}\right.$ at $\left.100^{\circ} \mathrm{C}\right)$ in order to liberate monosaccharides from structural carbohydrates (S, Hecky et al. 1973, Mopper 1977). Carbohydrates in both fractions were then analyzed by the phenol sulfuric acid method (Dubois et al. 1956). Filters for TEP were then analyzed by the colorimetric method of Passow \& Alldredge (1995) and expressed as Gum Xanthan equivalent (Xeq). 


\subsection{Potential $\beta$-glucosidase and alkaline phosphatase activities}

Ectoenzymatic $(0.2-3 \mu \mathrm{m}$ and $>3 \mu \mathrm{m})$ and extracellular $(<0.2 \mu \mathrm{m})$ activities were measured by the fluorometric method with methylumbelliferyl (MUF) substrates (Hoppe 1983) on unfiltered (total activities) and two prefiltered seawater samples $(<0.2 \mu \mathrm{m}$ and $<3 \mu \mathrm{m})$. A saturating concentration of substrate $(250 \mu \mathrm{M}$ 4-Methylumbelliferyl phosphate MUF-P, $100 \mu \mathrm{M}$ MUF- $\beta$-D-glucopyranoside) was used in order to reach the maximal velocity rate of alkaline phosphatase activity (APA) and $\beta$ Glc. The complete set of results presented in the present study are thus indicative of potential APA and $\beta$ Glc. For both activities, $2 \mathrm{ml}$ duplicate samples and respective controls were incubated with $50 \mu \mathrm{l}$ of substrate solution for $3 \mathrm{~h}$ in the dark at temperature and $\mathrm{pH}$ of the cultures. The hydrolysis reaction was halted by the addition of a $4 \%$ final concentration of formaldehyde for APA and $200 \mu$ l of a buffered (pH 10.5) solution of $0.2 \mathrm{M} \mathrm{NH}_{4} \mathrm{Cl} / 0.05$ M glycine for $\beta$ Glc. These inhibitors were added before the addition of substrate for controls. Both samples and controls were deep frozen. Fluorescence, produced by the 4Methylumbelliferone (MUF) released, was measured by flow injection analysis coupled with a fluorescence spectrometer (Kontron SFM 25, excitation at $364 \mathrm{~nm}$ and emission at $460 \mathrm{~nm})$. A buffered solution of borate $(0.1 \mathrm{M}, \mathrm{pH} 10.5)$ was used as the carrier fluid, providing maximum MUF fluorescence (Hoppe 1983, Chrost \& Krambeck 1986). The system was previously calibrated with MUF solutions. The $>3 \mu \mathrm{m}$ activities were calculated as the difference between total and $<3 \mu \mathrm{m}$ activities, and the 0.2-3 $\mu \mathrm{m}$ activities as the difference between $<3 \mu \mathrm{m}$ and $<0.2 \mu \mathrm{m}$ activities. The $0.2-3 \mu \mathrm{m}$ APA is due to free bacteria while attached bacteria and $T$. weissflogii both contribute to the > 
$3 \mu \mathrm{m}$ APA and cannot be separated by size fractionation. Since phytoplankton is not known to produce $\beta$-glucosidase ectoenzymes (Chrost 1989), only attached bacteria contribute to the $>3 \mu \mathrm{m} \beta$ Glc. In addition, no $\beta$ Glc was found in the $<0.2 \mu \mathrm{m}$ fraction. We are confident that the increase in MUF fluorescence for APA and $\beta$ Glc was linear over the single incubation time used (3h) given that 0.02 to $12 \%$ of MUF-P and 0.02 to $0.08 \%$ of MUF- $\beta$-D-glucopyranoside were hydrolyzed only at the end of incubation. The statistical calculations (standard deviation from culture triplicates) and tests (Mann \& Whitney, Spearman correlation) were performed with Excel software (Microsoft) using computing utilities from https://www.anastats.fr

\section{Results}

\subsection{Nutrient culture conditions, diatom and bacteria growth curves}

Low $\mathrm{PO}_{4}$ concentrations were measured in $\mathrm{P}$ deplete conditions from $16 \mathrm{~h}(0.05 \pm 0.01$ $\mu \mathrm{M})$ to $88 \mathrm{~h}(0.01 \pm 0.004 \mu \mathrm{M})$, whereas nitrate plus nitrite and silicate concentrations remained high (Fig. 2a). By contrast, in $\mathrm{P}$ replete conditions, the fast Thalassiosira weissflogii growth exhausted $\mathrm{PO}_{4}$ and nitrate plus nitrite after $88 \mathrm{~h}$ (Fig. 2b) while silicate remained high. Since T. weissflogii growth could have induced N, P and C co-limitation in $\mathrm{P}$ replete treatment after $88 \mathrm{~h}$, only results from the first 4 days of growth are representative of replete conditions and presented in the study. T. weissflogii cell number increased tenfold between $16 \mathrm{~h}$ and $88 \mathrm{~h}$ (Fig. 3) with a cell specific growth rate of 0.73 $\pm 0.16 \mathrm{~d}^{-1}$ (mean $\pm 95 \%$ confidence interval). By contrast, diatom growth was initially low in $\mathrm{P}$ deplete conditions $\left(0.48 \mathrm{~d}^{-1}\right)$, before ceasing altogether after $40 \mathrm{~h}$. Total bacteria 
cell growth was very closely linked to that of $T$. weissflogii for both P treatments (Fig. 3). Total bacteria and particle-attached bacteria abundances normalized to that of $T$. weissflogii were higher in $\mathrm{P}$ deplete than in $\mathrm{P}$ replete conditions throughout the time of experience (Fig. 4a, b). Attached bacteria contributed to $39 \pm 8 \%$ and $34 \pm 4 \%(\mathrm{n}=12)$ of the total bacteria abundance in $\mathrm{P}$ deplete and replete conditions, respectively (not shown).

\subsection{Physiological indicators of two different cell $P$ states}

Several physiological parameters indicate that $T$. weissflogii and bacteria actually developed two different physiological states according to the $\mathrm{P}$ treatment (Table 1). $\mathrm{Q}_{\mathrm{P}}$ was 4 times lower in $\mathrm{P}$ deplete than in $\mathrm{P}$ replete treatments. By contrast, $\mathrm{Q}_{\mathrm{C}}$, and $\mathrm{Q}_{\mathrm{N}}$ were only slightly lower in P deplete than in P replete conditions. QSi was approximately 50\% lower in $\mathrm{P}$ replete than in $\mathrm{P}$ deplete conditions at $88 \mathrm{~h}$ whereas it was quite similar at 16 h. $\mathrm{Q}_{\mathrm{Si}}$ is usually found to be inversely related to growth rate under non-silicon limitation (Martin-Jézéquel et al. 2000). At low growth rate, the silicification of the cells may be increased (elongation of the $\mathrm{G} 2+\mathrm{M}$ phase of the cell cycle during which major uptake of

silicon occurs, Claquin et al. 2002), resulting in higher Si:C ratio in P depleted cells compared to $\mathrm{P}$ repleted cells. The low $\mathrm{Si}: \mathrm{C}$ ratio at $88 \mathrm{~h}$ in $\mathrm{P}$ repleted cells could indicate the imminent onset of $\mathrm{C}$ limitation. The $\mathrm{C}: \mathrm{P}$ and $\mathrm{N}: \mathrm{P}$ atomic ratios in particulate matter were far greater than the Redfield ratio (106 and 16) in P deplete cultures, whereas they were approximately half the Redfield ratio in P replete conditions. For both cultures, the $\mathrm{C}: \mathrm{N}$ atomic ratio increased after four days. This ratio was higher in $\mathrm{P}$ depleted than in $\mathrm{P}$ repleted cells, which could be an indicator of cells being less healthy after $64 \mathrm{~h}$ of severe 
depletion. The PIP contributions to TPP were higher in $\mathrm{P}$ replete than in $\mathrm{P}$ deplete treatments and these values decreased in the two treatments from $16 \mathrm{~h}$ to $88 \mathrm{~h}$. P repleted cells stocked more $\mathrm{P}$ as phosphate, pyro- and polyphosphate forms (luxury uptake) and used reserve $\mathrm{P}$ to support diatom growth. This reserve of inorganic $\mathrm{P}$ may have been used for diatom survival in P depleted cells as shown by the low PIP contribution to the TPP at the beginning of the growth. These results concur with previous studies on $\mathrm{P}$ limited cells compared with non-limited or N limited cells (See review in Labry et al. 2013, their Table 5).

Both diatom and bacterial $\mathrm{PO}_{4}$ uptake were limited in $\mathrm{P}$ deplete conditions. The $\mathrm{PO}_{4}$ concentration $(0.009-0.052 \mu \mathrm{M})$ was close to or lower than the values of the half saturation constant $(\mathrm{Kt})+$ the natural substrate concentration $(\mathrm{Sn})$ for $\mathrm{PO}_{4}$ uptake, as already reported in severely P limited environments for phytoplankton $(0.056-0.090 \mu \mathrm{M})$ and bacteria $\left(0.002-0.038 \mu \mathrm{M}\right.$, Labry et al. 2002). The $\mathrm{PO}_{4}$ concentration at $88 \mathrm{~h}$ in $\mathrm{P}$ replete cultures $(0.063 \mu \mathrm{M})$ was consequently limiting for diatom $\mathrm{PO}_{4}$ uptake. Alkaline phosphatase activity (APA) is sensitive to $\mathrm{PO}_{4}$ concentration and as such, is commonly used as an indicator of bacterio- and phytoplankton P limitation (Labry et al. 2005). Specific particulate APA (i.e. particulate APA normalized to TPP), and specific free bacteria APA were 500 times and 5 to 44 times higher in $\mathrm{P}$ deplete than in $\mathrm{P}$ replete conditions, respectively (Table 1). In the $\mathrm{P}$ deplete conditions, bacteria $\mathrm{P}$ limitation was indicated by the high level of specific free bacteria APA, i.e. in a range of values (17 143 pmol per $10^{6}$ cells $^{-1}$ ) already reported for severely P-limited free bacteria in coastal waters (1 - 99 pmol per $10^{6}$ cells $^{-1}$, Labry et al. 2005). 


\subsection{Particulate and dissolved carbohydrates}

The total particulate reserve and structural $\mathrm{CHO}(\mathrm{R}+\mathrm{S})$ concentrations increased for both cultures and were more than twice as high in $\mathrm{P}$ replete than in $\mathrm{P}$ deplete conditions at 88 h (Table 2). However, the cell numbers differed between $\mathrm{P}$ treatments due to different growth rates, being five times higher in $\mathrm{P}$ replete conditions at $88 \mathrm{~h}$ than in $\mathrm{P}$ deplete conditions (Fig. 3). When normalized to diatom cell numbers, $\mathrm{R}$ and $\mathrm{S}$, were twice as high under $\mathrm{P}$ deplete than under $\mathrm{P}$ replete conditions (Fig. 5a). The maximum value obtained for $\mathrm{R}\left(372 \pm 20 \mathrm{pg} \mathrm{cell}^{-1}\right)$ was comparable with reserve $\beta$-glucan concentrations previously reported for T. weissflogii (from 364 to $412 \mathrm{pg}^{\text {cell }}{ }^{-1}$, Storseth et al. 2005). In both treatments, R largely dominated over the $\mathrm{S}$ (Fig. 5b). The R / S ratios were greater $(\mathrm{p}<0.001$, Mann \& Whitney test) in P depleted (range from 5.9 to 6.6) than in P repleted cells (range from 4.0 to 5.5). Reserve $\mathrm{CHO}$ staid constant in $\mathrm{P}$ replete, while it increased in $\mathrm{P}$ deplete between 40 and $64 \mathrm{~h}$ before stabilizing until $88 \mathrm{~h}$. Simultaneously, the concentrations of TEP increased in $\mathrm{P}$ replete from $40 \mathrm{~h}$ to $88 \mathrm{~h}$ and were higher than in $\mathrm{P}$ deplete cultures where the TEP concentrations start to increase when reserve $\mathrm{CHO}$ stabilized (Fig. 6a). They showed very similar values to $\mathrm{S}$ with which a significant correlation was found (Spearman correlation coefficient $r=0.61, \mathrm{n}=11, \mathrm{p}<0.05$ for $\mathrm{P}$ deplete cultures; $r=0.92, \mathrm{n}=10, \mathrm{p}<0.001$ for $\mathrm{P}$ replete cultures Fig. $6 \mathrm{~b}$ ).

Regarding the dissolved compartment, the T-DCHO concentrations were always higher under P deplete than under P replete conditions and displayed a slight increase over time (Table 2). The P-DCHO concentrations were similar for both cultures, while M-DCHO concentrations were approximately twice as high in $\mathrm{P}$ deplete than in $\mathrm{P}$ replete cultures 
(Table 2). It should be noted that, for both conditions, the M-DCHO concentrations remained remarkably constant over time while the P-DCHO concentrations increased. The ratio of P-DCHO to M-DCHO was far lower in P deplete $(0.15-0.30)$ than in $\mathrm{P}$ replete conditions $(0.37-1.09)$.

\section{4. $\beta$-glucosidase activities}

Total potential $\beta$ Glc showed higher values in $\mathrm{P}$ deplete than in $\mathrm{P}$ replete treatment (Fig. 7a). Attached bacteria dominated potential $\beta$ Glc throughout the experiment both in $P$ deplete and P replete conditions, with cell count contributions of $78 \pm 3 \%$ and $65 \pm 6 \%$ $(\mathrm{n}=12)$, respectively (not shown). They developed a greater enzymatic potential to hydrolyze polysaccharides than their free-living counterparts, as suggested by the higher specific $\beta$ Glc calculated separately for attached and free bacteria (Fig. 7b). This pattern is even more pronounced under P deplete conditions: specific $\beta$ Glc of attached bacteria were 4.6 to 6.8 times greater than that of free bacteria in this condition whereas they were only 2.6 to 4.6 times higher in P replete treatments (Fig 7b).

\section{Discussion}

Phytoplankton and specifically diatoms are known to be important producers of polysaccharides and exopolymers (Hoagland et al. 1993). Bacterioplankton may also release polysaccharides (Passow 2002a, Panhota et al. 2007). However, bacteria cannot be considered a net producer of particulate and dissolved $\mathrm{CHO}$. Bacteria are heterotrophs and between 50 and $90 \%$ of the Carbon taken up by bacteria in aquatic ecosystems is 
mineralized (Del Giorgio \& Cole 1998). Through a decay experiment using glucose as Carbon source, Panhota et al. (2007) showed that the production of polysaccharides by a natural bacterial community represented less than $2 \%$ of the glucose degradation products; $94.4 \%$ being mineralized. Gärdes et al. (2011) demonstrated that the major source of polysaccharides in Thalassiosira weissflogii and bacteria co-cultures was photosynthetically active $T$. weissflogii. In our cultures, bacterial C contributed to $3 \%$ of POC only, while particulate carbohydrate Carbon constituted 65 and $79 \%$ of POC in P replete and $\mathrm{P}$ deplete cultures, respectively. Bacteria were only minor contributors of particulate and dissolved polysaccharides in our cultures. However, their enzymatic equipment for polymer hydrolysis could have modified the composition of polysaccharides.

\subsection{Speciation of particulate carbohydrates}

The present study highlights that $\mathrm{P}$ deplete conditions promote accumulation of carbohydrates in diatom cells, mainly as reserve polysaccharides: the ratio of Reserve to Structural polysaccharides, R / S, is higher (5.9 to 6.6) than in P repleted cells (4.0 to 5.5). This may explain the high $\mathrm{C}: \mathrm{N}$ ratio found at the end of incubation in $\mathrm{P}$ deplete cultures whereas it remained quite constant in P replete conditions (Suroy et al. 2015). There are very few data on $\mathrm{R}$ versus $\mathrm{S}$ partition of carbohydrates in phytoplankton. Granum \& Myklestad (2002) found a similar R / S ratio in the late exponential phase of axenic Skeletonema costatum cultures (3.8) and a far higher ratio in the N limited stationary phase (15.5). By contrast, they reported lower R / S values (0.34 to 0.84$)$ for natural nutrient sufficient phytoplankton communities, with an equal composition of diatoms and 
haptophytes. Haptophyte cell walls are composed of several layers of cellulose and complex polysaccharides, which explains the higher S contribution. In the same way, natural communities substantially comprising dinoflagellates whose cell walls are made up of insoluble glucan as cellulose, lead to low R / S ratio (<0.5, Haug et al. 1973). The partition between $\mathrm{R}$ and $\mathrm{S}$ actually depends on the relative composition of plankton species. However, according to the present study and that of Granum \& Myklestad (2002), a higher contribution of diatoms in microalgal communities could lead to a higher $\mathrm{R}$ polysaccharide proportion in particulate matter. This proportion is increased in $\mathrm{P}$ deplete conditions. Since R in diatoms are essentially composed of glucose polymers (Myklestad \& Haug 1972, Granum et al. 2002), the consequence may be a higher bioavailable pool of carbohydrates in the dissolved environment when cells become senescent, die and lyse.

TEP are operationally defined as discrete exopolymer particles that can be stained with alcian blue due to the presence of anionic carboxyl and sulfate half ester groups (Passow 2002b, Passow \& Alldredge 1995). By definition, TEP should not include cell coatings. For both culture conditions, concentrations of particulate S and TEP were quantitatively very similar and were significantly correlated. It is well known that diatom $\mathrm{S}$ polysaccharides are essentially composed of mannose, glucuronic acid and sulfate groups (Ford \& Percival 1965, Chiovitti et al. 2005, Tesson \& Hildebrand 2013). These chemical groups represent the key factors for the staining of polysaccharides with alcian blue (Ramus 1977). Passow (2002b) as well as Engel et al. (2004) indicated that the colorimetric method may overestimate TEP if organisms with stainable coatings are abundant. Thus, we suspect that the acidic S polysaccharides associated with the frustules 
constitute the major part of the analyzed TEP in our diatom cultures. Real TEP were of unknown importance.

\subsection{Speciation of dissolved carbohydrates}

Dissolved $\mathrm{CHO}$ in the form of mono- and polysaccharides correspond to "functional pools" with respect to bacterial nutrition dynamics. Indeed, M-DCHO can be directly taken up by bacteria, whereas P-DCHO need to be hydrolyzed by glucosidases before being taken up as monosaccharides (Fig. 8). As in the present study, Borsheim et al. (2005) found low fluctuations of M-DCHO over time in mesocosms receiving contrasted nutrient supplies and supporting a diatom bloom and its decline. They assumed a tight coupling between the production of $\mathrm{M}-\mathrm{DCHO}$ and their uptake by heterotrophic bacteria. In addition, their M-DCHO concentrations did not differ over a gradient of daily nutrient supply. In the present study, the balance between production and uptake occurs at two different levels according to $\mathrm{P}$ condition, as illustrated in Fig. 8. The difference comes from either a higher hydrolysis of P-DCHO or a lower uptake of M-DCHO in P deplete conditions compared to $\mathrm{P}$ replete conditions, or both. The very high level of potential $\beta$ Glc found as early as $16 \mathrm{~h}$ after inoculation in $\mathrm{P}$ deplete conditions is an indicator of a high P-DCHO hydrolysis, even if these activities are not actual in situ rates (see Discussion below, Section 4.3). Micro-organisms have a high enzymatic capacity for polymer hydrolysis.

Concerning the bacterial uptake of M-DCHO, it seems not to have been limited by the M-DCHO concentrations in our cultures $(4.6-10.3 \mu \mathrm{M})$. These concentrations were far higher than the range of $\mathrm{Kt}+\mathrm{Sn}$ for glucose uptake, as already reported in brackish $(0.009$ 
$-0.038 \mu \mathrm{M}$ Glucose, Gocke et al. 1981) and oligotrophic waters (0.043-0.220 $\mu \mathrm{M}$, Ayo et al. 2001). In addition, there is no evidence in the literature that $\mathrm{P}$ depletion can change the M-DCHO composition into aldoses that are more resistant to bacterial degradation. On the contrary, a higher contribution of glucose, one of the most bioavailable aldoses (Hama \& Yanagi 2001), was found in P depleted diatom exudates compared to P replete cell exudates (Urbani et al. 2005). Alternatively, bacteria were found to be $\mathrm{PO}_{4}$ limited in the $\mathrm{P}$ deplete conditions, as highlighted by their reduced growth rate, the $\mathrm{PO}_{4}$ concentration close to reported $\mathrm{Kt}+\mathrm{Sn}$ values for bacterial $\mathrm{PO}_{4}$ uptake, and the very high level of specific APA for free bacteria. As a consequence of reduced growth rate, the uptake of M-DCHO must have also been reduced. Thus, high specific $\beta$ Glc and reduced uptake of M-DCHO can explain the high M-DCHO concentration observed in P deplete cultures (Fig.8). As in Borsheim et al. (2005), the increase in P-DCHO with time in our cultures suggests that their excretion by phytoplankton became higher with time compared to their hydrolysis by bacteria (Fig. 8).

\subsection{Enzymatic responses of free and attached bacteria}

Enzymatic measurements provide potential activities (enzymatic equipment) since there is no data on actual hydrolysis rates which are not biased by the competitive inhibition between natural and artificial substrates necessary for their measurement. In our study, the ratio between saturating artificial $(100 \mu \mathrm{M})$ and natural substrate (1.5 to $5.5 \mu \mathrm{M}$ PDCHO) is high enough to avoid this competitive inhibition. If bacteria are not net $\mathrm{CHO}$ producers in the two $\mathrm{P}$ treatments, they could have modified the $\mathrm{CHO}$ composition excreted by $T$. weissflogii via their enzymatic equipment and, ultimately, have changed 
their ability to aggregate particles. The very high values of potential specific $\beta$ Glc in $\mathrm{P}$ deplete treatment as early as $16 \mathrm{~h}$ after inoculation have resulted in the observed high $\mathrm{M}$ DCHO concentrations found in these cultures (see Discussion above, Section 4.2). These very high activities can be explained both by an induction of $\beta$-glucosidases synthesis a few hours after the beginning of incubation, and by the bacteria present, those coming from the diatom precultures, which may have already been equipped with a significant amount of glucosidases. Whatever their origin, the major contributors to these high potential $\beta$ Glc are bacteria attached to $>3 \mu \mathrm{m}$ particles. In term of bacterial cell numbers, they are the lowest contributors. Such differences in specific $\beta$ Glc between attached and free bacteria have already been observed on natural and artificial phytoplankton aggregates (Karner \& Herndl 1992, Agis et al. 1998) and during the development and decline of a phytoplankton bloom (Middelboe et al. 1995). The present study emphasizes the fact that $\mathrm{P}$ limitation promotes free and attached bacteria having higher cell-specific $\beta$ Glc than in $\mathrm{P}$ replete conditions and with a higher ratio of attached to free bacterial activity. P limitation may increase the difference between free and attached bacterial enzymatic equipment for polysaccharide hydrolysis.

\subsection{Consequences for labile DOC accumulation}

Saad et al. (2016) found that dissolved CHO represented $30 \%$ of the dissolved organic carbon (DOC) production in both low $\mathrm{P}$ and $\mathrm{P}$ replete axenic cultures of $T$. pseudonana. Similar values were observed for T. weissflogii cultures (28\%; Aluwihare \& Repeta 1999), and from mesocosm experiments with natural planktonic population (18-21\%; Meon \& Kirchman 2001). Using an average value of $24 \%$, we can roughly estimate DOC 
concentrations in our P deplete (from 290 to $330 \mu \mathrm{M}$ ) and P replete conditions (from 160 to $260 \mu \mathrm{M}$ ). These values are in the range generally found in such experiments (> 200 $\mu \mathrm{M})$. DOC accumulation may have represented up to $100 \%$ of POC in P deplete conditions. It decreased from 70 to $15 \%$ of $\mathrm{POC}$ in $\mathrm{P}$ replete experiments as diatom biomass increased. Such difference between replete conditions (i.e. blooming phase), and nutrient deplete conditions (post bloom) concurs with the accumulation of carbon rich dissolved organic matter observed in surface marine environments (Thingstad et al. 1997, Williams 1995). This accumulation was attributed to the imbalance between excretion and lysis processes consecutive to the decline of blooms, and reduction of bacterial uptake caused by nutrient depletion. As we observed in our experiments, $\mathrm{P}$ depletion of heterotrophic bacteria favors labile DOC accumulation (Fig. 8; Vadstein et al. 2003).

\section{Conclusions}

Our results show that $\mathrm{P}$ depletion favors firstly diatom carbohydrate accumulation, mainly in the form of $\mathrm{R} \mathrm{CHO}$, and their subsequent cell release. The $\mathrm{R} / \mathrm{S}$ ratio is high in diatom cultures and increases with $\mathrm{P}$ depletion. A high contribution of diatoms in microalgal communities could lead to high proportion of polysaccharides as reserve pools in particulate matter. In addition, the fact that bacteria were also $\mathrm{P}$ depleted might have stressed this accumulation of reserve polysaccharides, by competing for phosphate. This promoted an active degradation (polysaccharide hydrolysis by $\beta$-glucosidases) by the bacterial communities, notably by attached bacteria. However bacterial growth and

metabolism were slowed down by P depletion, and consequently the uptake of M-DCHO was reduced. P depletion of heterotrophic bacteria favored M-DCHO accumulation. This 
is in accordance with the accumulation of degradable DOC observed in surface marine waters. The $\mathrm{P}$ status of bacteria must be considered to evaluate the effect of $\mathrm{P}$ depletion on carbohydrate dynamics and subsequent consequences for particle potential aggregation.

\section{Acknowledgements}

We wish to thank J. Devesa for particulate C, N analysis, and A. Curd for English language corrections.

\section{Funding}

This work was supported by the "Laboratoire d'Excellence" LabexMER (ANR-10LABX-19-01).

\section{Literature cited}

Agis M, Unanue M, Iriberri J, Herndl GJ (1998) Bacterial colonization and ectoenzymatic activity in phytoplankton-derived model particles. Part II. Cleavage and uptake of carbohydrates. Microb Ecol 36:66-74

Aluwihare LI, Repeta DJ (1999) A comparison of the chemical characteristics of oceanic DOM and extracellular DOM produced by marine algae. Mar Ecol Prog Ser 186:105117 
Aminot A, Kerouel R, Coverly SC (2009) Nutrients in seawater using segmented flow analysis. In: Wurl O. (Ed), Practical guidelines for the analysis of seawater. CRC Press., Boca Raton, p 143-178

Aspila KI, Agemian H, Chau AS (1976) A semi-automated method for the determination of inorganic, organic and total phosphate in sediments. Analyst 101:187-197

Ayo B, Unanue M, Azua I, Gorsky G, Turley C, Iriberri J (2001) Kinetics of glucose and amino acid uptake by attached and free-living marine bacteria in oligotrophic waters. Mar Biol 138:1071-1076

Biersmith A, Benner R (1998) Carbohydrates in phytoplankton and freshly produced dissolved organic matter. Mar Chem 63:131-144

Borsheim KY, Vadstein O, Myklestad SM, Reinertsen H, Kirkvold S, Olsen Y (2005) Photosynthetic algal production, accumulation and release of phytoplankton storage carbohydrates and bacterial production in a gradient in daily nutrient supply. J Plankton Res 27:743-755

Burney CM, Sieburth JMcN (1977) Dissolved carbohydrates in seawater. II, A spectrophotometric procedure for total carbohydrate analysis and polysaccharide estimation. Mar Chem 5:15-28 
Chiovitti A, Harper RE, Willis A, Bacic A, Mulvaney P, Wetherbee R (2005) Variations in the substituted 3-linked mannans closely associated with the silicified walls of diatoms. J Phycol 41:1154-1161

Chrost RJ (1989) Characterization and significance of $\beta$-glucosidase activity in lake water. Limnol Oceanogr 34:660-672

Chrost RJ, Krambeck HJ (1986) Fluorescence correction for measurements of enzyme activity in natural waters using methylumbelliferyl-substrates. Archiv Hydrobiol 106:7990

Claquin P, Martin-Jézéquel V, Krompkamp JC, Veldhuis MJW, Kraay GW (2002) Uncoupling of silicon compared with carbon and nitrogen metabolisms and the role of the cell cycle in continuous cultures of Thalassiosira pseudonana (bacillariophyceae) under light, nitrogen, and phosphorus control. J Phycol 38:922-930

Cotner JB, Ammerman JW, Peele ER, Bentzen E (1997) Phosphorus-limited bacterioplankton growth in the Sargasso Sea. Aquat Microb Ecol 13:141-149

Del Giorgio PA, Cole JJ (1998) Bacterial growth efficiency in natural aquatic ecosystems. Annu Rev Ecol Syst 29:503-541

Dubois M, Gilles KA, Hamilton JK, Rebers PA, Smith F (1956) Colorimetric method for determination of sugars and related substances. Anal Chem 28:350-356 
Engel A, Delille B, Jacquet S, Riebesell U, Rochelle-Newall E, Terbrüggen A, Zondervan

I (2004) Transparent exopolymer particles and dissolved organic carbon production by Emiliania huxleyi exposed to different $\mathrm{CO} 2$ concentrations: a mesocosm experiment. Aquat Microb Ecol 34:93-104

Ford CW, Percival E (1965) The carbohydrates of Phaeodactylum tricornutum. Part II. A sulphated glucuronomannan. J Chem Soc 0:7042-7046

Gärdes A, Iversen MH, Grossart HP, Passow U, Ullrich MS (2011) Diatom-associated bacteria are required for aggregation of Thalassiosira weissflogii. Int Soc Microb Ecol J $5: 436-445$

Gocke K, Dawson R, Liebezeit G (1981) Availability of dissolved free glucose to heterotrophic microorganisms. Mar Biol 62:209-216

Granum E, Myklestad SM (2002) A simple combined method for determination of $\beta-1,3-$ glucan and cell wall polysaccharides in diatoms. Hydrobiologia 477:155-161

Granum E, Kirkvold S, Myklestad SM (2002) Cellular and extracellular production of carbohydrates and amino acids by the marine diatom Skeletonema costatum: diel variations and effects of N depletion. Mar Ecol Prog Ser 242:83-94

Grizzetti I, Bouraoui F, Aloe A (2012) Changes of nitrogen and phosphorus loads to European seas. Glob. Change Biol 18:769-782 
Guerrini F, Mazzotti A, Boni L, Pistocchi R (1998) Bacterial-algal interactions in polysaccharide production. Aquat Microb Ecol 15:247-253

Guillard RRL, Ryther JH (1962) Studies on marine plankton diatoms. I Cyclotella nana Husted and Detonela confervacea (Cleve) Gran. Can J Microbiol 8:229-239

Hama T, Yanagi K (2001) Production and neutral aldose composition of dissolved carbohydrates excreted by natural marine phytoplankton populations. Limnol Oceanogr 46:1945-1955

Handa N (1969) Carbohydrate metabolism in the marine diatom Skeletonema costatum. Mar Biol 4:208-214

Handa N, Tominaga H (1969) A detailed analysis of carbohydrates in marine particulate matter. Mar Biol 2:228-235

Haug A, Myklestad S, Sakshaug E (1973) Studies on the phytoplankton ecology of the Trondheimsfjord. I. The chemical composition of phytoplankton populations. J Exp Mar Biol Ecol 11:15-26

Hecky RE, Mopper K, Kilham P, Degens ET (1973) The amino acid and sugar composition of diatom cell-Walls. Mar Biol 19:323-331 
Hoagland KD, Rosowski JR, Gretz MR, Roemer SC (1993) Diatom extracellular polymeric substances: function, fine structure, chemistry and physiology. J Phycol 29:537-566

Hoppe HG (1983) Significance of exoenzymatic activities in the ecology of brackish water: measurements by means of methylumbelliferyl-substrates. Mar Ecol Prog Ser 11:299-308

Karl DM, Bjorkman KM, Dore JE, Fujieki L, Hebel DV, Houlihan T, Letelier RM, Tupas LM (2001) Ecological nitrogen-to-phosphorus stoichiometry at station ALOHA. DeepSea Res. II 48:1529-1566

Karner M, Herndl GJ (1992) Extracellular enzymatic activity and secondary production in free-living and marine-snow-associated bacteria. Mar Biol 113:341-347

Labry C, Herbland A, Delmas D (2002) The role of phosphorus on planktonic production of the Gironde plume waters in the Bay of Biscay. J Plankton Res 24:97-117

Labry C, Delmas D, Herbland A (2005) Phytoplankton and bacterial alkaline phosphatase activities in relation to phosphate and DOP availability within the Gironde plume waters (Bay of Biscay). J Exp Mar Biol Ecol 318:213-225 
Labry C, Youenou A, Delmas D, Michelon P (2013) Addressing the measurement of particulate organic and inorganic phosphorus in estuarine and coastal waters. Continental Shelf Res 60:28-37

Le Costaouëc T, Unamunzaga C, Mantecon L, Helbert W (2017) New structural insights into the cell-wall polysaccharide of the diatom Phaeodactylum tricornutum. Algal Res 26:172-179

Lee S, Fuhrman JA (1987) Relationships between biovolume and biomass of naturally derived marine bacterioplankton. Applied Environ Microbiol 53:1298-1303

Lomas MW, Burke AL, Lomas DA, Bell DW, Shen C, Dyhrman ST, Ammerman JW (2010) Sargasso Sea phosphorus biogeochemistry: an important role for dissolved organic phosphorus (DOP). Biogeosciences 7:695-710

Magaletti E, Urbani R, Sist P, Ferrari CR, Cicero AM (2004) Abundance and chemical characterization of extracellular carbohydrates released by the marine diatom Cylindrotheca fusiformis under N- and P-limitation. European J Phycol 39:133-142

Mari X, Passow U, Migon C, Burd AB, Legendre L (2017) Transparent exopolymer particles: Effects on carbon cycling in the ocean. Progress in Oceanogr 151:13-37

Martin-Jezequel V, Hildebrand M, Brzezinski MA (2000) Silicon metabolism in diatoms: Implications for growth. J Phycol 36:821-840 
Meon B, Kirchman DL (2001) Dynamics and molecular composition of dissolved organic material during experimental phytoplankton blooms. Mar Chem 75:185-199

Middelboe M, Sondergaard M, Letarte Y, Borch NH (1995) Attached and free-living bacteria: Production and polymer hydrolysis during a diatom bloom. Microb Ecol 29:231-248

Mopper K (1977) Sugars and uronic acids in sediments and water from the Black Sea and North Sea with emphasis on analytical techniques. Mar Chem 5:585-603

Murphy J, Riley JP (1962) A modified single solution method for the determination of phosphate in natural waters. Anal Chim Acta 27:31-36

Myklestad S. (1974) Production of carbohydrates by marine planktonic Diatoms. I. Comparison of nine different species in culture. J Exp Mar Biol Ecol 15:261-274

Myklestad S (1995) Release of extracellular products by phytoplankton with special emphasis on polysaccharides. Science Total Environ 165:155-164

Myklestad S, Haug A (1972) Production of carbohydrates by the marine diatom Chaetoceros affinis var. willei (gran) Hustedt. I. Effect of the concentration of nutrients in the culture medium. J Exp Mar Biol Ecol 9:125-136 
Myklestad S, Skanoy E, Hestmann S (1997) A sensitive and rapid method for analysis of dissolved mono- and polysaccharides in seawater. Mar Chem 56:279-286

Obata T, Fernie AR, Nunes-Nesi A (2013) The central carbon and energy metabolism of marine diatoms. Metabolites 3:325-346

Panhota RS, Bianchini Jr I, Vieira AAH (2007) Glucose uptake and extracellular polysaccharides (EPS) produced by bacterioplankton from an eutrophic tropical reservoir (Barra Bonita, SP-Brazil). Hydrobiologia 583:223-230

Passow U (2002a) Production of transparent exopolymer particles (TEP) by phyto- and bacterioplankton. Mar Ecol Prog Ser 236:1-12

Passow U (2002b) Transparent exopolymer particles (TEP) in aquatic environments. Progress in Oceanogr 55:287-333

Passow U, Alldredge AL (1995) A dye-binding assay for the spectrophotometric measurement of transparent exopolymer particles (TEP). Limnol Oceanogr 40:13261335

Penna A, Berluti S, Penna N, Magnani M (1999) Influence of nutrient ratios on the in vitro extracellular polysaccharide production by marine diatoms from the Adriatic Sea. $\mathbf{J}$ Plankton Res 21:1681-1690 
Penuelas J, Poulter B, Sardans J, Ciais P, van der Velde M, Bopp L, Boucher O, Godderis Y, Hinsinger P, Llusia J, Nardin E, Vicca S, Obersteiner M, Janssens IA (2013) Humaninduced nitrogen-phosphorus imbalances alter natural and managed ecosystems across the globe. Nature Comm 4:2934

Porter KG, Feig YS (1980) The use of DAPI for identifying and counting aquatic microflora. Limnol Oceanogr 25:943-948

Ragueneau O, Savoye N, Del Amo Y, Cotton J, Tardiveau B, Leynaert A (2005) A new method for the measurement of biogenic silica in suspended matter of coastal waters: using Si:Al ratios to correct for the mineral interference. Continental Shelf Res 25:697710

Ramus J (1977) Alcian blue: a quantitative aqueous assay for algal acid and sulfated polysaccharides. J Phycol 13:345-348

Saad EM, Longo AF, Chambers LR, Huang R, Benitez-Nelson C, Dyhrman ST, Diaz JM, Tang Y, Ingall ED (2016) Understanding marine dissolved organic matter production: Compositional insights from axenic cultures of Thalassiosira pseudonana. Limnol Oceanogr 61:2222-2233

Simon M, Alldredge AL, Azam F (1990) Bacterial carbon dynamics on marine snow. Mar Ecol Prog Ser 65:205-211 
Solorzano L, Sharp JH (1980) Determination of total dissolved phosphorus and particulate phosphorus in natural waters. Limnol Oceanogr 25:754-758

Staats N, Stal LJ, Mur LR (2000) Exopolysaccharide production by the epipelic diatom Cylindrotheca closterium: effects of nutrient conditions. J Exp Mar Biol Ecol 249:13-27

Storseth TR, Hansen K, Reitan KI, Skjermo J (2005) Structural characterization of $\beta$-D$(1 \rightarrow 3)$-glucans from different growth phases of the marine diatoms Chaetoceros mülleri and Thalassiosira weissflogii. Carbohydrate Res 340:1159-1164

Suroy M, Panagiotopoulos C, Boutorh J, Goutx M, Moriceau B (2015) Degradation of diatom carbohydrates: A case study with N- and Si- stressed Thalassiosira weissflogii. J Exp Mar Biol Ecol 470:1-11

Tesson B, Hildebrand M (2013) Characterization and localization of insoluble organic matrices associated with diatom cell walls: insight into their roles during cell wall formation. Plos One 8:e61675

Thingstad TF, Hagstrom A, Rassoulzadegan F (1997) Accumulation of degradable DOC m surface waters: Is it caused by a malfunctioning microbial loop? Limnol Oceanogr $42: 398-404$

Thingstad TF, Zweifel UL, Rassoulzadegan F (1998) P limitation of heterotrophic bacteria and phytoplankton in the northwest Mediterranean. Limnol Oceanogr 43:88-94 
Urbani R, Magaletti E, Sist P, Cicero AM (2005) Extracellular carbohydrates released by the marine diatoms Cylindrotheca closterium, Thalassiosira pseudonana and Skeletonema costatum: Effect of P-depletion and growth status. Sci Total Environ $353: 300-306$

Vadstein O, Olsen LM, Busch A, Andersen T, Reinertsen HR (2003) Is phosphorus limitation of planktonic heterotrophic bacteria and accumulation of degradable DOC a normal phenomenon in phosphorus-limited systems? A microcosm study. FEMS Microbiol Ecol 46:307-316

Varum KM, Ostgaard K, Grimsrud K (1986) Diurnal rhythms in carbohydrate metabolism of the marine diatom Skeletonema costatum (Grev.) Cleve. J Exp Mar Biol Ecol 102:249-256

Velji MI, Albright LJ (1986) Microscopic enumeration of attached marine bacteria of seawater, marine sediment, fecal matter, and kelp blade following pyrophosphate and ultrasound treatments. Can J Microb 32:121-126

Williams PJ leB (1995) Evidence for the seasonal accumulation of carbon-rich dissolved organic material, its scale in comparison with changes in particulate material and the consequential effect on net $\mathrm{C} / \mathrm{N}$ assimilation ratios. Mar Chem 51:17-29 
Table 1

2

\begin{tabular}{|c|c|c|c|c|}
\hline \multirow{2}{*}{ Physiological parameters } & \multicolumn{2}{|c|}{ P- } & \multicolumn{2}{|c|}{$\mathbf{P +}$} \\
\hline & $16 \mathrm{~h}$ & $88 \mathrm{~h}$ & $16 \mathrm{~h}$ & $88 \mathrm{~h}$ \\
\hline $\mathrm{Q}_{\mathrm{C}}\left(\mathrm{pmol} \mathrm{C}\right.$ cell $\left.^{-1}\right)$ & $11(2)$ & $11(1)^{*}$ & $13(1)$ & $13(1)$ \\
\hline $\mathrm{Q}_{\mathrm{N}}\left(\mathrm{pmol} \mathrm{N}\right.$ cell $\left.^{-1}\right)$ & $1.5(0.1)$ & $1.2(0.2)$ & $1.9(0.3)$ & $1.6(0.1)$ \\
\hline $\mathrm{Q}_{\mathrm{P}}\left(\mathrm{pmol} \mathrm{P}\right.$ cell $\left.^{-1}\right)$ & $0.068(0.007)$ & $0.035(0.001)$ & $0.244(0.009)$ & $0.143(0.015)$ \\
\hline $\mathrm{Q}_{\mathrm{Si}}\left(\mathrm{pmol} \mathrm{Si} \mathrm{cell}{ }^{-1}\right)$ & $4.8(0.7)$ & $3.4(0.3)$ & $4.2(0.1)$ & $1.5(0.1)$ \\
\hline $\mathrm{C}: \mathrm{N}$ at:at & $7.6(0.9)$ & $10.5(0.6)^{*}$ & $7.0(0.5)$ & $7.9(0.01)$ \\
\hline $\mathrm{Si}: \mathrm{C}$ at:at & $0.5(0.1)$ & $0.4(0.1)^{*}$ & $0.3(0.0)$ & $0.1(0.0)$ \\
\hline $\mathrm{C}: \mathrm{P}$ at:at & 167 (19) & $266(24) *$ & $54(8)$ & $89(2)$ \\
\hline $\mathrm{N}: \mathrm{P}$ at:at & $22(1)$ & $33(4)$ & $8(2)$ & $11(0.3)$ \\
\hline $\operatorname{PIP}(\%)$ & $41(4)$ & $31(2)^{*}$ & $56(2)$ & $34(1)$ \\
\hline APA $>0.2 \mu \mathrm{m}\left(\mathrm{nmol} \mathrm{P} \mu \mathrm{mol} \mathrm{TPP}{ }^{-1} \mathrm{~h}^{-1}\right)$ & $1487(242)$ & $10110(796)$ & $2(1)$ & $18(2)$ \\
\hline APA $0.2-3 \mu \mathrm{m}\left(\mathrm{pmol} P 10^{6}\right.$ cells $\left.^{-1} \mathrm{~h}^{-1}\right)$ & $17(3)$ & $143(24)$ & $3(1)$ & $3(1)$ \\
\hline
\end{tabular}

3 
2 Table 2

3

\begin{tabular}{ccccccccc}
\hline \multirow{2}{*}{ Time (h) } & \multicolumn{9}{c}{ P- } & \multicolumn{3}{c}{ P+ } \\
\cline { 2 - 8 } & R+S & M-DCHO & P-DCHO & T-DCHO & R+S & M-DCHO & P-DCHO & T-DCHO \\
\hline 16 & $17 \pm 1$ & $10.3 \pm 0.1$ & $1.5 \pm 0.1$ & $11.8 \pm 0.1$ & 14 & $4.7 \pm 0.1$ & $1.7 \pm 0.2$ & $6.4 \pm 0.3$ \\
40 & $37 \pm 1$ & $10.3 \pm 0.0$ & $2.0 \pm 0.1$ & $12.4 \pm 0.1$ & $47 \pm 6$ & $4.6 \pm 0.1$ & $2.2 \pm 0.3$ & $6.8 \pm 0.2$ \\
64 & $62 \pm 2$ & $10.3 \pm 0.1$ & $3.1 \pm 0.3$ & $13.4 \pm 0.2$ & $89 \pm 6$ & $4.7 \pm 0.0$ & $3.3 \pm 0.1$ & $8.0 \pm 0.1$ \\
88 & $78 \pm 6$ & $10.3 \pm 0.0$ & $2.9 \pm 0.5$ & $13.2 \pm 0.5$ & $176 \pm 31$ & $5.0 \pm 0.3$ & $5.5 \pm 0.1$ & $10.5 \pm 0.2$ \\
\hline
\end{tabular}

6

8 


\section{Thalassiosira weissflogii precultures} and their respective bacterial consortiums
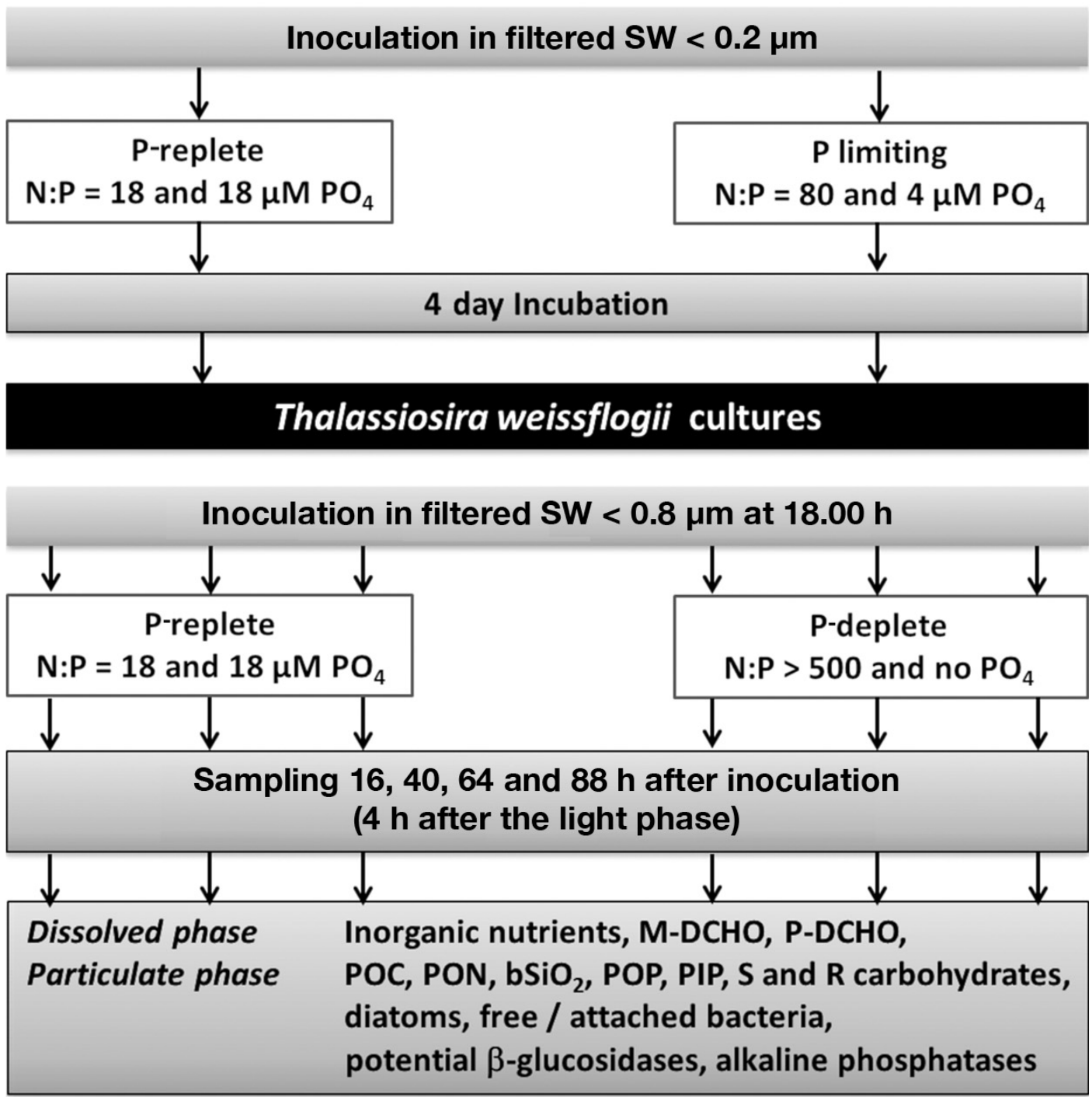
1 Fig. 2

2
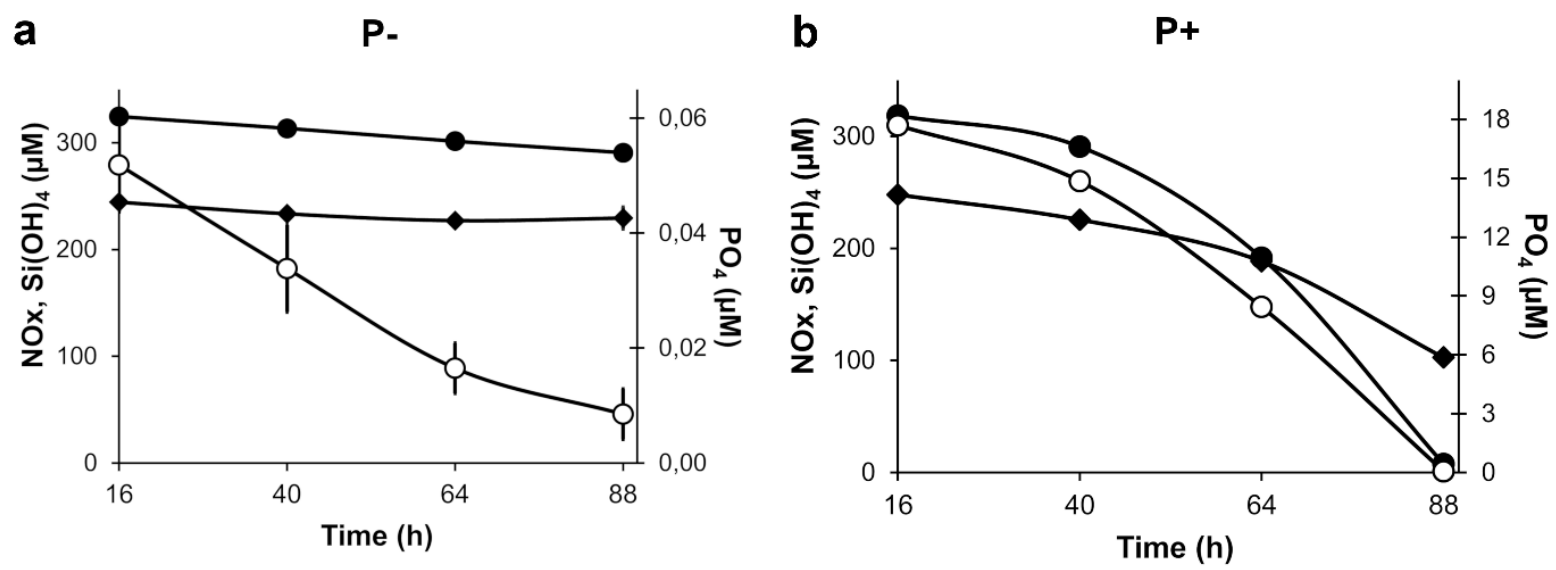

3

4

5

Fig. 3

6

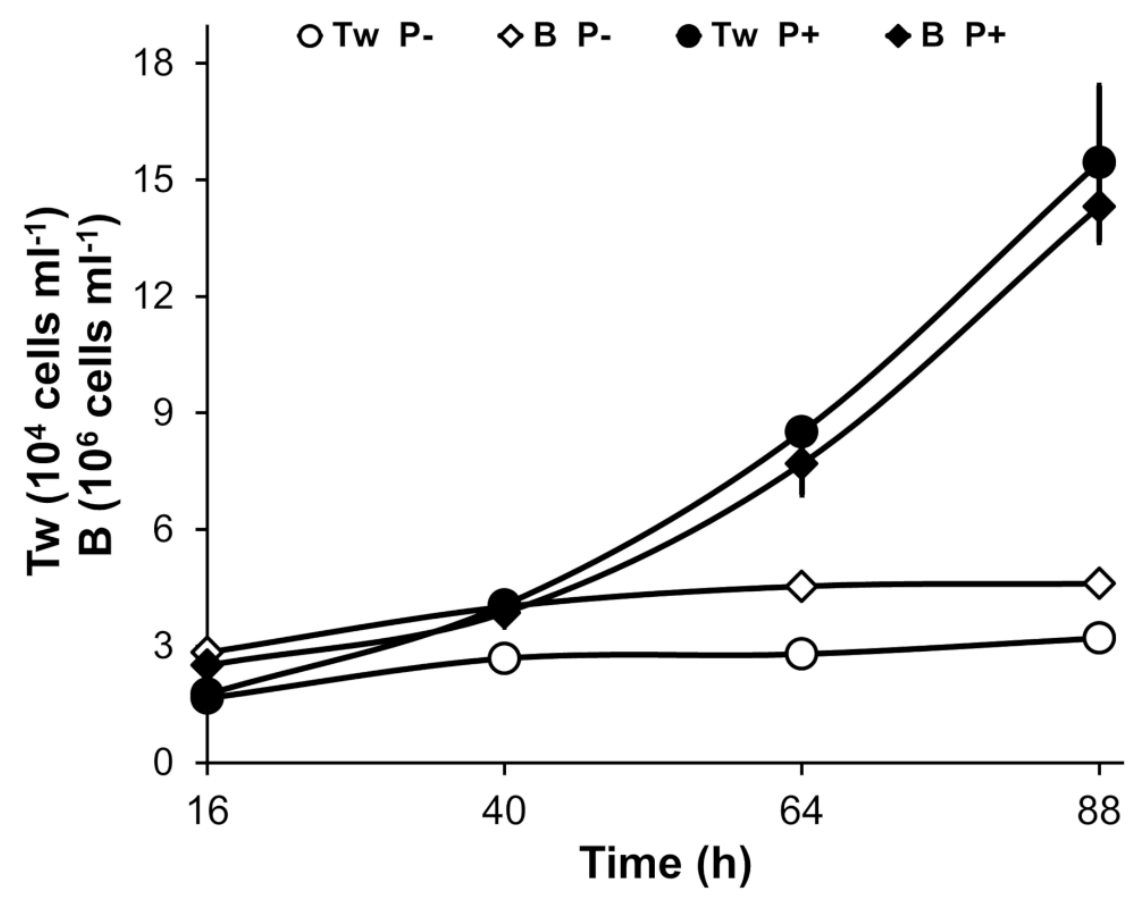


$1 \quad$ Fig. 4

2

a

OP- ๑P+

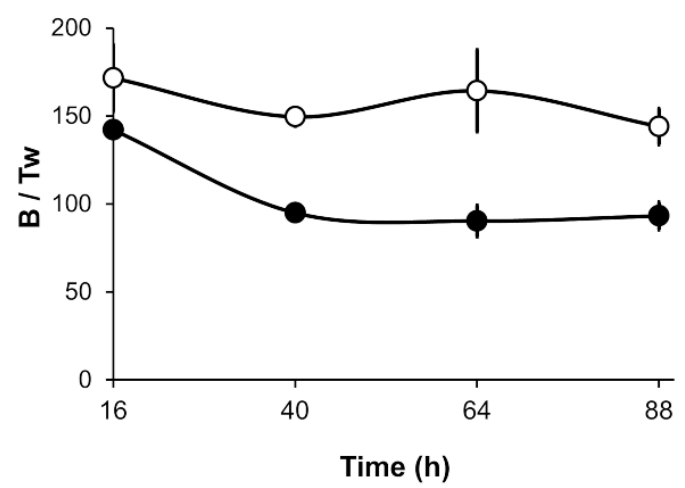

3

4

5

6

a

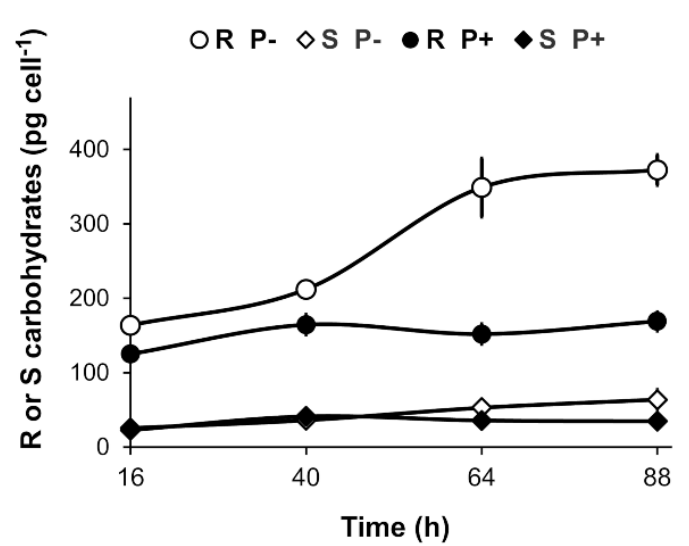

7

8

9

10

11 b $\quad$ OP. $\bullet P+$

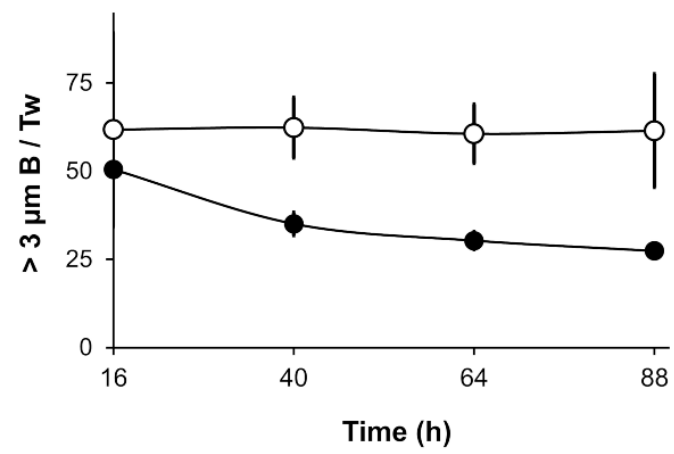

b

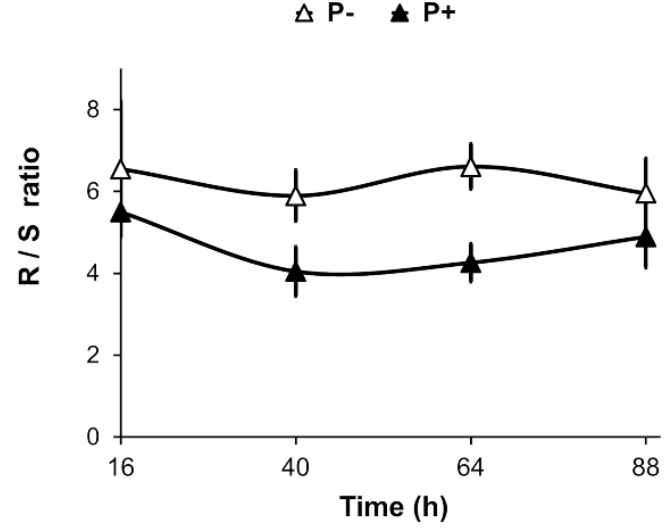


1 Fig. 6

2
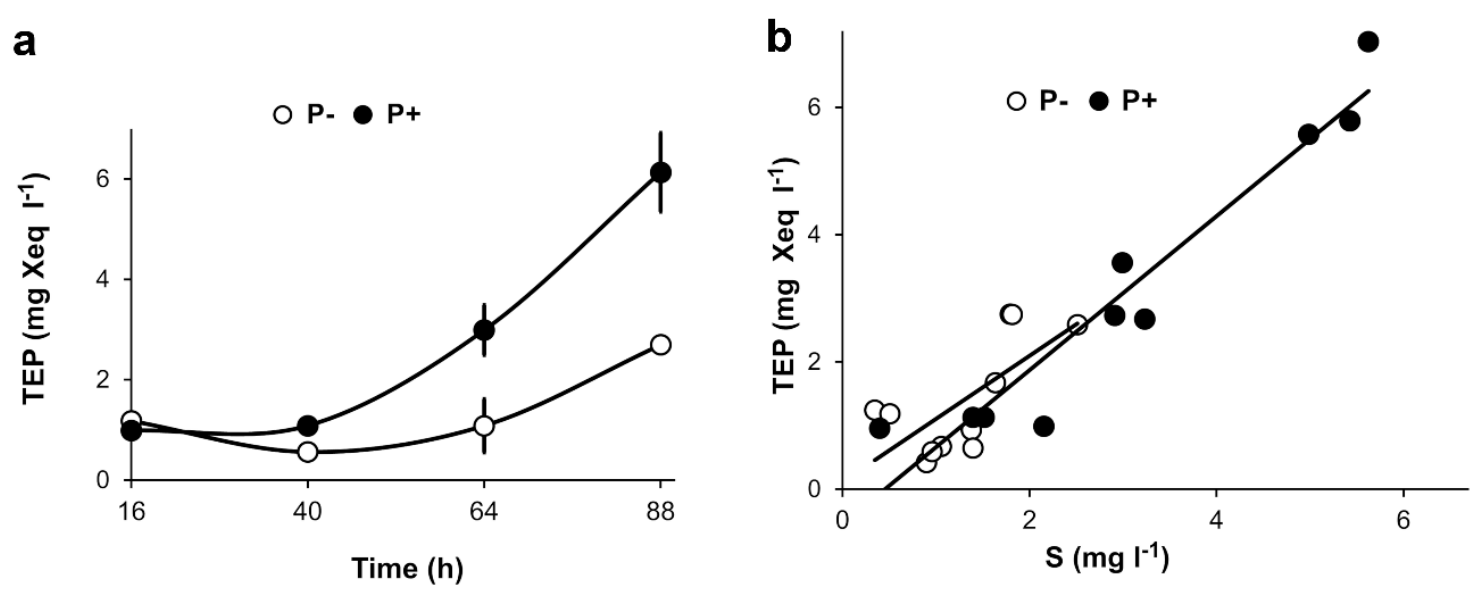

3

4

5

$\begin{array}{ll}6 & \text { Fig. } 7\end{array}$

7

a

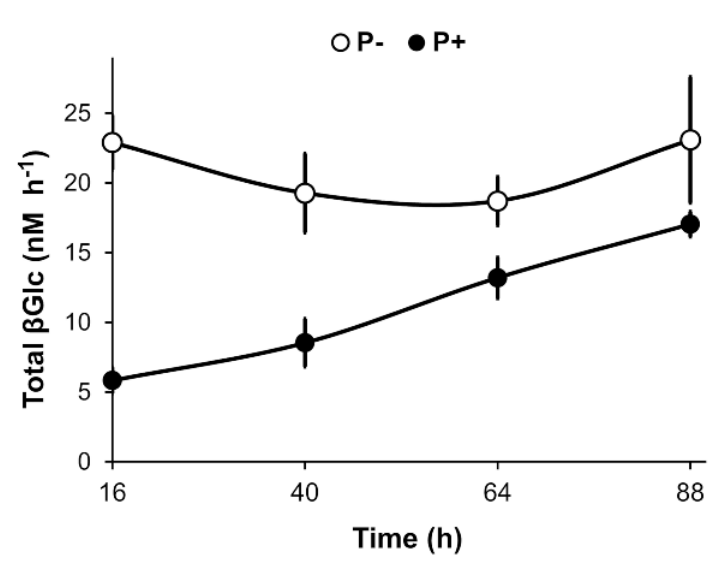

b

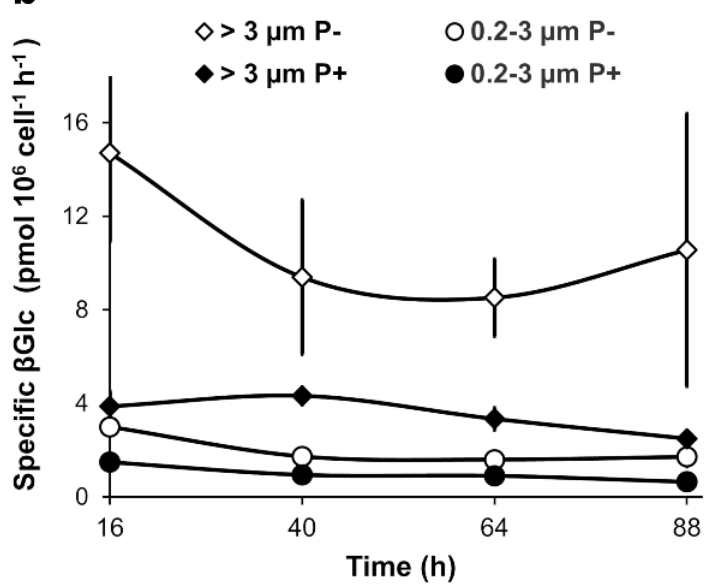

8

9 
1 Fig. 8

2

\section{P deplete}

\section{P replete}

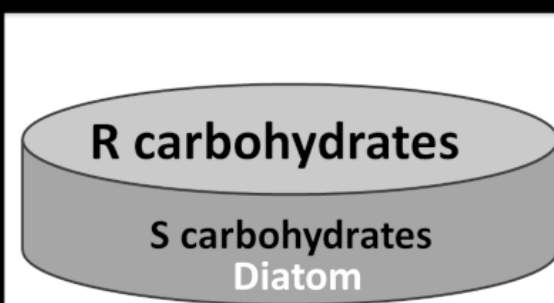

R carbohydrates

S carbohydrates

Diatom

Excretion, cell lysis

P-DCHO

$$
\text { P-DCHO }
$$

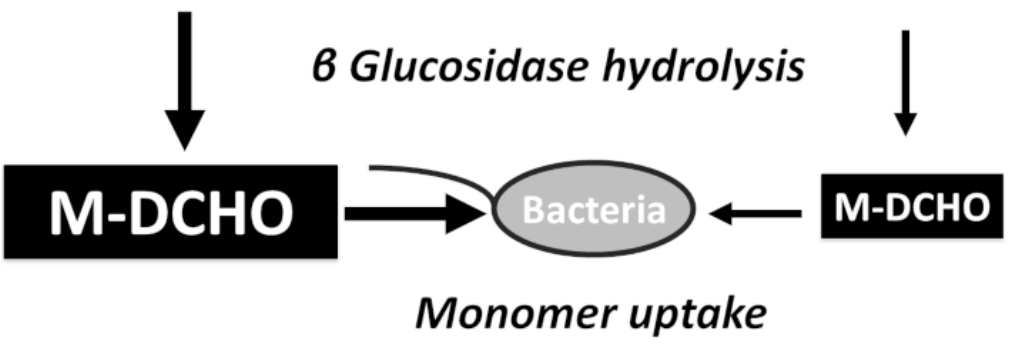

3

4

5

6 


\section{$1 \quad$ Tables and Figures}

2

3 Table 1. Mean values (standard deviation, $\mathrm{n}=3$ ) on $16 \mathrm{~h}$ and $88 \mathrm{~h}$ of the cellular $\mathrm{C}, \mathrm{N}, \mathrm{P}$

4 and Si content of Thalassiosira weissflogii $\left(\mathrm{Q}_{\mathrm{C}}, \mathrm{Q}_{\mathrm{N}}, \mathrm{Q}_{\mathrm{P}}, \mathrm{Q}_{\mathrm{Si}}\right)$, the particulate C:N, Si:C,

$5 \mathrm{C}: \mathrm{P}$, and $\mathrm{N}: \mathrm{P}$ atomic ratios, the PIP contribution to TPP $(\%)$, specific particulate APA per

$6 \quad$ TPP and specific $0.2-3 \mu \mathrm{m}$ APA per bacterial cell for the $\mathrm{P}$ deplete $(\mathrm{P}-)$ and replete $(\mathrm{P}+)$

7 cultures. * indicates values on $64 \mathrm{~h}$ rather than $88 \mathrm{~h}$.

8

9 Table 2. Mean values of particulate carbohydrates (reserve plus structural, $\mathrm{R}+\mathrm{S}$ ), 10 dissolved mono- (M-DCHO), polysaccharides (P-DCHO) and total dissolved 11 carbohydrates $(\mathrm{T}-\mathrm{DCHO})$ concentrations $(\mu \mathrm{M})$ for the $\mathrm{P}$ deplete $(\mathrm{P}-)$ and replete $(\mathrm{P}+)$ 12 cultures of Thalassiosira weissflogii. The standard deviations correspond to triplicate 13 cultures $(n=3)$ for particulate carbohydrate analysis and triplicate measurements on 14 triplicate cultures $(n=9)$ for all dissolved carbohydrate forms.

16 Fig. 1. Experimental set-up of Thalassiosira weissflogii precultures and cultures

Fig. 2. Nitrate plus nitrite (black dots, left scale), silicate (black diamonds, left scale) and phosphate (empty dots, right scale) concentrations $(\mu \mathrm{M})$ in $\mathrm{P}$ deplete $(\mathrm{P}-$, a) and $\mathrm{P}$ replete $(\mathrm{P}+, \mathrm{b})$ Thalassiosira weissflogii cultures. Error bars illustrate the standard deviation corresponding to culture triplicates. All error bars are shown. 
1 Fig. 3. Thalassiosira weissflogii (Tw, dots) and bacterial abundance ( $\mathrm{B}$, diamonds) in $\mathrm{P}$

2 deplete (P-, empty symbols) and $\mathrm{P}$ replete $(\mathrm{P}+$, full symbols) cultures. Error bars illustrate

3 the standard deviation corresponding to culture triplicates. All error bars are shown.

4

5 Fig. 4. The ratio of (a) total and (b) attached (> $3 \mu \mathrm{m})$ bacteria to Thalassiosira weissflogii 6 in $\mathrm{P}$ deplete $(\mathrm{P}-)$ and $\mathrm{P}$ replete $(\mathrm{P}+)$ cultures. Error bars illustrate the standard deviation 7 corresponding to culture triplicates. All error bars are shown.

9 Fig. 5. Reserve (R) and structural (S) particulate carbohydrates normalized to 10 Thalassiosira weissflogii cells (a) and the $\mathrm{R} / \mathrm{S}$ ratio (b) in $\mathrm{P}$ deplete $(\mathrm{P}-)$ and $\mathrm{P}$ replete $11(\mathrm{P}+)$ cultures. Error bars illustrate the standard deviation corresponding to culture triplicates. All error bars are shown.

Fig. 6. Total transparent exopolymer particles (TEP) in $\mathrm{P}$ deplete $(\mathrm{P}-)$ and $\mathrm{P}$ replete $(\mathrm{P}+)$ cultures (a) and their relationship with structural particulate polysaccharides (b). Error bars illustrate the standard deviation corresponding to culture triplicates. All error bars are shown.

Fig. 7. Total potential $\beta$-glucosidase activities $\left(\beta G l c, n M h^{-1}\right.$, a) and specific $\beta$ Glc normalized to bacterial cells for attached $(>3 \mu \mathrm{m})$ and free $(0.2-3 \mu \mathrm{m})$ bacteria (pmol $10^{6}$ cells $\left.^{-1} \mathrm{~h}^{-1}, \mathrm{~b}\right)$ in $\mathrm{P}$ deplete $(\mathrm{P}-)$ and $\mathrm{P}$ replete $(\mathrm{P}+)$ cultures. Error bars illustrate the standard deviation corresponding to culture triplicates. All error bars are shown. 
1 Fig. 8. Representation of the dissolved mono- (M-DCHO) and polysaccharides (P-

2 DCHO) and particulate reserve (R) and structural (S) carbohydrate pools and cell specific

3 fluxes in $\mathrm{P}$ deplete and $\mathrm{P}$ replete culture conditions for diatoms and bacteria.

4 